За матеріалами науково-практичної конференції

«Заклади охорони здоров’я та виробники лікарських засобів: ефективне співробітництво у процесі медикаментозного забезпечення населення України»

УДК 614.2-616.24-053.2(477)

В. В. ТРОХИМЧУК ${ }^{1}$, д-р фарм. наук, проф.,

О. І. БСЛЯСВА르, канд. фарм. наук., Л. М. УНГУРЯН ${ }^{2}$, д-р фарм. наук, доцент

${ }^{1}$ Національна медична академія післядипломної освіти імені П. Л. Шупика, м. Київ

${ }^{2}$ Одеський національний медичний університет

ОРГАНІЗАЦІЯ НАДАННЯ МЕДИЧНОЇ ДОПОМОГИ ДІТЯМ В УКРАЇНІ (ОГЛЯД ЛІТЕРАТУРИ)

Ключові слова: діти, охорона здоров'я, медична допомога, ліки

\author{
V. V. TROKHIMCHUK ${ }^{1}$, O. I. BELYAEVA ${ }^{2}$, L. M. UNHURIAN ${ }^{2}$ \\ ${ }^{1}$ Shupyk National Medical Academy of Post-graduate Education, Kyiv \\ ${ }^{2}$ Odesa National Medical University
}

\title{
ORGANIZATION OF MEDICAL CARE FOR CHILDREN IN UKRAINE (REVIEW OF LITERATURE)
}

Key words: children, medications, healthcare, medical care

Особливе значення в системі охорони здоров'я України займає охорона дитинства внаслідок іiі важливості для розвитку суспільства та забезпечення інтересів кожної сім'ї або громадянина. ВООЗ визначає: життя, виживання, максимальний розвиток, доступ дітей до служб охорони здоров'я $є$ не лише їхніми фундаментальними потребами, але й основними правами людини. Реалізація прав дітей на оздоровлення, належне медичне і фармацевтичне обслуговування є важливим стратегічним завданням нашої держави [1-4].

В Україні в процесі реформування системи охорони здоров'я постійну увагу приділяють вирішенню найактуальніших проблем, що стосуються збереження здоров’я дітей, а саме зниженню показників малюкової смертності, дитячої захворюваності та інвалідності. Ці напрями - розвиток профілактичних заходів, побудову нових структурних лікувально-профілактичних підрозділів, проведення національних і регіональних епідеміологічних і клінічних досліджень, виходячи з результатів яких можна буде в подальшому простежувати і контролювати ситуацію з найактуальніших проблем педіатрії. Реалізація медичних і фармацевтичних заходів високої якості, спрямованих на охорону здоров'я дітей, залишається важливим питанням на етапі реформування вітчизняної медицини $[5,6]$.

Особливого значення названі дослідження набувають за умов реформування вітчизняної системи охорони здоров'я у напрямі побудови соціально орієнтованих моделей фармацевтичного забезпечення населення та формування відповідної законодавчої та нормативно-правової бази у рамках упровадження обов'язкового медичного страхування [7].

Завдання нашої роботи - вивчити та проаналізувати систему медичної допомоги дітям в Україні.

\section{М ат е р і али т а ме тоди дослідження}

Об'єктом дослідження були нормативно-правові акти, що регулюють організацію медичної допомоги дітям, дані наукової літератури із зазначеної проблеми. Методами дослідження обрано інформаційний, ретроспективний, історичний, логічний, аналітичний.

(C) Колектив авторів, 2017 


\section{Р езультати дослідження та обговоре ння}

Стан здоров'я дітей в Україні є незадовільним у зв'язку із тенденцією до зростання захворюваності, поширеності хвороб та інвалідності. Процес депопуляції, що спостерігається в Україні починаючи з 1990 р., набув характеру демографічної кризи, в умовах якої збереження життя і здоров'я кожної дитини набирає надзвичайно важливого загальнодержавного значення.

Залишається високим рівень інвалідності серед дітей, що є одним із найнесприятливіших явищ у комплексі характеристик стану здоров'я та соціального благополуччя населення. Не вдається уникнути тенденції до зростання кількості дітей-сиріт і дітей, позбавлених батьківського піклування $[8,9]$.

Статистичні дані переконливо свідчать про значну поширеність хронічної патології в дітей, і стан їхнього здоров’я можна характеризувати як катастрофічний. До такої ситуації призвели економічні труднощі, зниження уваги до соціальних проблем, безперервне неадекватне реформування системи освіти, проблеми ранньої трудової зайнятості, збільшення інтенсивності впливу на дітей і підлітків факторів екологічного та медико-соціального ризику, погіршення структури харчування, зниження ефективності проведення традиційних профілактичних заходів, висока захворюваність та збільшення кількості соціально дезадаптованих дітей [10-12].

Гострота вказаних проблем саме для системи охорони здоров'я дітей пояснюється низкою причин:

- відсутністю пріоритетного фінансування заходів щодо охорони здоров'я дітей;

- недостатньою взаємодією всіх органів влади та відомств щодо реалізації державної політики стосовно охорони здоров'я;

- ослабленням в останні роки уваги до реалізації профілактичного напряму, який в охороні здоров’я дітей має бути пріоритетним;

- незадовільною динамікою щодо забезпеченості кадрами насамперед первинної ланки та лікарями саме тих спеціальностей (педіатрами, неонатологами тощо), діяльність яких безпосередньо впливає на рівень смертності та інвалідності дітей;

- недостатньою спрямованістю науково-дослідних робіт щодо основних напрямів, які вирішують завдання стосовно виживання та розвитку дітей на основі науково-доказової медицини та медико-економічної доцільності;

- невідповідністю сучасним потребам рівня оснащеності медичним обладнанням та санітарним транспортом закладів охорони здоров'я, де надається медична допомога дітям і матерям;

- недостатньою інформованістю населення щодо здорового способу життя, раціонального харчування, профілактики інфекційних захворювань, збереження репродуктивного здоров'я тощо [13-19].

Таким чином, ситуація, яка складається сьогодні із здоров'ям дітей, потребує негайного розв'язання проблем загальнодержавного характеру, що може бути досягнуто шляхом здійснення державної політики у галузі охорони здоров'я через економічні, соціальні та інші важелі.

Завдання держави щодо збереження і зміцнення здоров'я дітей забезпечується виконанням положень Конвенції ООН про права дитини, яка була ратифікована Парламентом України 27. 09. 1991 р. Так, стаття 24 Конвенції визначає право дитини на користування найбільш досконалими послугами системи охорони здоров'я та засобами лікування хвороб і відновлення здоров'я, забезпечення права кожної дитини на доступ до подібних послуг системи охорони здоров'я. Україна, як учасниця ВООЗ, має здійснювати відповідні медичні заходи, визнані ВООЗ як найбільш економічно доцільні $[20,4]$. 
В України відповідно до Європейської стратегії ВООЗ «Здоров’я та розвиток дітей і підлітків» передбачаються заходи щодо вдосконалення нормативно-правової бази в напрямі охорони здоров'я дітей; вдосконалення організації спеціалізованої екстреної допомоги та системи надання первинної медико-санітарної допомоги дітям в умовах розвитку сімейної медицини; поліпшення матеріально-технічного забезпечення закладів охорони здоров'я, де надається медична допомога дітям та ін.

На першому етапі нашого дослідження виконано аналіз нормативно-правових документів із питань реалізації надання медичної допомоги дітям в Україні. Державна політика нашої країни у галузі охорони здоров'я визначається Конституцією України, законодавством України про охорону здоров'я, про охорону дитинства та іншими нормативно-правовими актами, що регулюють суспільні відносини у галузі охорони здоров’я. Так, у ст. 49 Конституції України зазначено, що охорона здоров'я забезпечується державним фінансуванням відповідних соціально-економічних, медико-санітарних та профілактичних програм; державою створюються умови для ефективного і доступного для всіх громадян медичного обслуговування; у державних і комунальних закладах охорони здоров'я медичну допомогу надають безоплатно [21-23]. Проте в умовах сьогодення забезпечити дотримання таких необмежених гарантій держава неспроможна, що свідчить про формальність та економічну необгрунтованість зазначених декларацій у Конституції України [22].

Державні гарантії щодо охорони здоров'я дитини також регулюються Законом України «Основи законодавства України про охорону здоров'я», який визначає, що медичну допомогу населенню, в т. ч. дітям і підліткам, забезпечують лікувальнопрофілактичні й оздоровчі заклади, дитячі поліклініки, відділення, диспансери, лікарні, санаторії та інші заклади охорони здоров'я [24]. За даними аналітиків [25-27, 22], на цей час в Україні необгрунтовано переобтяжена в кількісному плані мережа лікарень, значна частина яких представлена малопотужними, погано оснащеними та малозавантаженими з погляду обсягу надання послуг закладами, що сприяє зниженню якості надання медичної допомоги та ефективності використання ресурсів.

У 2009 р. було прийнято нормативний документ, який мав стратегічне значення у сфері охорони дитинства, а саме Закон України «Про загальнодержавну програму «"Національний план дій щодо реалізації Конвенції ООН про права дитини” на період до 2016 року». Цей документ мав за мету забезпечення оптимального функціонування цілісної системи захисту прав дітей в Україні відповідно до вимог Конвенції ООН про права дитини та з урахуванням Цілей розвитку, проголошених Декларацією тисячоліття ООН і підсумкового документа Спеціальної сесії в інтересах дітей Генеральної Асамблеї ООН «Світ, сприятливий для дітей». На виконання цієї програми уряд щорічно затверджував План заходів. Основним заходом для підвищення якості та збільшення обсягу медичних послуг згідно з Планом було розроблення стандартів надання медичної допомоги; уніфікованих клінічних протоколів та використання їх у процесі підвищення кваліфікації лікарів загальної практики та сімейної медицини в частині надання медичної допомоги дітям. Тому наступним етапом нами зроблено аналіз Реєстру медико-технологічних документів, в якому наведено сучасні документи останніх років, розроблені на засадах доказової медицини. Визначено, що станом на січень 2017 р. до Реєстру медико-технологічних документів за напрямом «Педіатрія» увійшло лише 35 документів [28]. Таким чином, не всі патологічні стани дитячого віку охоплено стандартизацією, що знижує якість надання медичної допомоги в цих випадках.

Основні заходи щодо впливу на поліпшення здоров'я дітей реалізовували в нашій країні також через різноманітні програмні документи. Визначено, що за період 1994-2016 рр. в Україні реалізовували такі державні програми: «Діти України», 
«Українська ініціатива по охороні здоров’я», «Програма контролю смертності серед жінок, малюків і дітей», «Програма 3 прав дитини», «Програма ліквідації йодозалежних захворювань», «Ініціатива лікарні, дружньої дитині», «Чорнобильський проект гуманітарної допомоги і реабілітації», «Проект Надія - експериментальна ініціатива по лікуванню туберкульозу», «Програма охорони здоров’я і розвитку молоді». Протягом періоду їх дії відбувалось навіть збільшення фінансового забезпечення деяких державних програм та централізованих заходів, спрямованих на охорону здоров'я дітей, що становило близько 1 млрд. грн [29]. Однак більшість заходів, передбачених цими програмами, залишились нереалізованими. На думку деяких авторів, серед причин такого стану реалізації програм виділяють наступні: недостатнє фінансування ухваленої програми; незлагоджена координація між виконавцями програми; відсутність дієвого моніторингу якості та результатів виконання державних програм.

На міжнародному рівні питання охорони здоров'я дітей передбачено у низці міжнародних програм, спрямованих на ії вдосконалення. Так, міжнародну допомогу дітям України надають установи ООН, Свропейський Союз (СС), Організація економічного співробітництва і розвитку, уряди США, Німеччини, Японії, Канади, Нідерландів, Великобританії, Франції, Швейцарії, Італії, Єгипту, а також низка міжнародних фундацій і неурядових організацій $[30-32,18]$.

Наша держава, підписавши у складі 189 країн світу в 1989 р. Декларацію тисячоліття Організації Об'єднаних Націй, що декларує боротьбу з бідністю і розвиток людини як основу для досягнення стійкого соціального та економічного розвитку, зобов'язалася досягти до 2015 р. зниження смертності дітей віком до 5 років на дві третини порівняно з 1990 р. Як результат, визначено, що в Україні станом на 2012 р. було досягнуто національної цілі щодо зменшення дитячої смертності. Однак, незважаючи на дострокове виконання взятих на себе країною зобов'язань у цій сфері, рівні смертності немовлят і дітей до 5 років залишаються у 2-4 рази вищими порівняно з розвинутими європейськими країнами [33]. Тому подальше зниження рівнів дитячої смертності в Україні можливе лише за умов удосконалення системи охорони здоров'я дитинства.

Відомо, що значна частина дитячої захворюваності та смертності пов'язана 35 причинами: гострими респіраторними інфекціями (в основному пневмоніями), діареєю, порушенням харчування, дитячими інфекціями, травмами тощо. Тому ВООЗ, дитячим фондом ООН ЮНІСЕФ і багатьма іншими організаціями, інститутами та приватними особами ВООЗ/ЮНІСЕФ розроблено стратегію «Інтегроване ведення хвороб дитячого віку» (IВХДВ, Integrated Management of Childhood Illness), яку впроваджено більш ніж у 100 країнах світу та яка передбачає низку заходів із профілактики та лікування цих основних захворювань як у медичному закладі, так і вдома $[34-37,2]$. Стратегія передбачає удосконалення медичної допомоги дітям до 5-ти років, адже 90\% смертей дітей у віці до 18 років припадає на перші 4 роки життя, щорічно у світі помирає близько 11 мільйонів дітей цього віку, або 1200 дітей кожну годину, 99\% померлих — це діти з країн, що розвиваються. Цей документ визначає алгоритми правильного ведення найпоширеніших серйозних проблем, з якими стикатимуться як медичні працівники первинної ланки медичної допомоги дітям, так і працівники стаціонару. Пріоритетний напрям стратегії ІВХДВ - первинна медико-санітарна допомога [34].

Необхідність впровадження цієї стратегії IBXДВ в Україні була пов'язана з цілою низкою причин. Серед них важливе значення мали обмежена кількість витратних матеріалів і устаткування в медичних установах першого рівня надання медичної допомоги дітям, недостатні знання й навички медичних працівників у консультуванні дітей і батьків та необхідність удосконалення базових знань ведення хворих і здорових дітей тощо [35]. 
Так, у 2010 р. наказом МОЗ України № 581 «Про впровадження стратегії інтегрованого ведення хвороб дитячого віку» визначено регіони для реалізації пілотного впровадження стратегії ІВХДВ, план заходів та приблизний перелік ЛЗ та виробів медичного призначення для використання в роботі лікарями-педіатрами та лікарями загальної практики-сімейної медицини в умовах реалізації стратегії ІВХДВ [36]. Для процесу впровадження стратегії IВХДВ у нашій державі було розроблено три складові:

1 - удосконалення системи охорони здоров'я, спрямованої на ефективне ведення хвороб дитячого віку;

2 - поліпшення у медичних працівників навичок ведення хворих дітей за допомогою адаптованих до місцевих умов засад IBХДВ та заходів щодо пропаганди їх використання;

3 - удосконалення практики догляду за дітьми раннього віку в сім'ях та громадах.

Результатом впровадження стратегії ІВХДВ стало зниження показників смертності дітей різних вікових груп у пілотних регіонах [33]. Таким чином, стратегія IBXДВ сприяє збільшенню ефективності надання медичної допомоги хворим дітям, що, в свою чергу, дасть змогу знизити в майбутньому витрати на ії застосування.

Далі нами проаналізовано моделі надання медичної допомоги дітям. Так, на сучасному етапі науковці визначають існування трьох моделей організації надання медичної допомоги дітям:

I - лікар-педіатр як первинна ланка надання медичної допомоги дітям;

II - лікар загальної практики/сімейний лікар виконує функції первинної ланки, а лікар-педіатр є консультантом;

III - комбінована система, що грунтується на перелічених моделях [37, 27].

Визначено, що серед 34 країн Європи тільки в 12-ти систему первинної медичної допомоги дітям організовано як педіатричну (І модель). Це такі країни, як Україна, Іспанія, Греція, Чехія, Болгарія, Литва та ін. Комбінована система (III модель) надання медичної допомоги дітям функціонує у 16 країнах Європи (Франція, Португалія, Німеччина, Польща, Туреччина, Латвія, Естонія, Швеція, Австрія та ін.). Та лише в 6 країнах Європи первинну медичну допомогу дітям надають лікарі загальної практики (II модель), зокрема у Великій Британії, Ірландії, Данії, Нідерландах, Норвегії, Фінляндії $[38,10,16]$. Стосовно вікового аспекту, діти у віці до 14 років обслуговуються тільки педіатрами у Греції, Чехії, Словаччині, Австрії, Швейцарії, Люксембурзі та Угорщині. 315 років пацієнтів спостерігає лікар загальної практики у Латвії, Люксембурзі та Іспанії. В Італії тільки діти з хронічною соматичною патологією можуть лікуватися у педіатра до досягнення ними 16-18-ти річного віку [39, 40].

Слід зазначити, що в деяких країнах (Голландія, Латвія, Німеччина та ін.) первинний рівень надання медичної допомоги дітям сімейними лікарями має негативні наслідки, такі як порівняно високий рівень дитячої смертності, збільшення показників дитячої захворюваності, неефективна програма вакцинації. Тому, на думку деяких авторів, комбінована модель надання медичної допомоги дитячому населенню в умовах реформування галузі охорони здоров'я є найбільш прийнятною [40].

На наступному етапі було проаналізовано організацію надання висококваліфікованої медичної допомоги дітям. Так, в Україні стаціонарна допомога хворим дітям надається в дитячих лікарнях (спеціалізованих або багатопрофільних) або дитячих відділеннях загальних лікарень. Важливою умовою існування дитячого стаціонару є забезпечення наступності в роботі з іншими ЛПЗ: поліклініками, санаторіями, пологовими будинками тощо. Сучасні умови їх існування передбачають необхідне упорядкування та більш рентабельне використання стаціонарного фонду з його подальшою спеціалізацію, розвиток інших форм, які замінюють стаціонари. Адже у 
дитячих стаціонарах не передбачено умов для перебування матерів, госпіталізованих для догляду за дітьми. Також існують диспропорції у доступі до медичних послуг міських і сільських жителів [15].

Далі нами було проаналізовано економічну доступність медичної допомоги в Україні. Визначено, що високим є рівень особистих витрат населення на послуги охорони здоров'я. Згідно з офіційною статистикою, витрати населення сягають майже половини загального обсягу фінансування галузі і здійснюються безпосередньо під час одержання медичних послуг [41]. Через надзвичайно низький рівень державних витрат на придбання лікарських засобів фактично всі необхідні для лікування, зокрема під час стаціонарного лікування, лікарські засоби змушені купувати батьки хворої дитини за власні кошти. За статистичними даними, витрати $з$ державних джерел (4,4\% ВВП) охоплюють лише 57\% від загального обсягу галузі охорони здоров'я $[42,43]$. Тобто існує невідповідність між реальним станом забезпечення дитячого населення у системі охорони здоров'я України та державними нормативними документами, за якими медична допомога має бути безкоштовною в державних та комунальних закладах охорони здоров'я.

Таким чином, на основі проведеного аналізу можливо зазначити необхідність суттєвих змін в організації надання медичної допомоги дітям, а саме: структурну реорганізацію галузі; оптимізацію ліжкового фонду; збільшення обсягів фінансування медичної допомоги з державного та місцевих бюджетів та підвищення ефективності використання ресурсів галузі охорони здоров'я; продовження розроблення та впровадження сучасних протоколів (стандартів) лікування патологій дитячого віку, розроблених на основі існуючої практики медичних втручань, технологій із доведеною ефективністю та фармакоекономічних досліджень.

\section{В и с н о в к и}

1. Здійснено аналіз вітчизняних нормативних документів із питань організації надання медичної допомоги дитячому населенню України. Встановлено їх формальний характер та економічну необгрунтованість.

2. Аналіз державних програм, які стосуються організації охорони здоров'я дітей, визначив, що більшість заходів, задекларованих у них, залишаються нереалізованими внаслідок недостатнього фінансування, незлагодженої координації між виконавцями програми, відсутності дієвого моніторингу якості та результатів виконання програм.

3. Значна кількість патологічних станів дитячого віку не охоплена медико-технологічними документами.

4. В Україні педіатрична допомога надається згідно з I моделлю. В умовах реформування галузі найбільш ефективною та прийнятною моделлю є комбінована (III модель).

5. Визначено недоліки стаціонарної допомоги дітям в Україні, а саме відсутність умов для перебування матерів, госпіталізованих для догляду за дітьми, наявність диспропорцій у доступі до медичних послуг міських і сільських жителів, малопотужність та погана оснащеність лікарняних закладів.

6. Визначено високий рівень витрат населення на послуги охорони здоров'я, що становить майже половину загального обсягу фінансування галузі.

\section{С пи сок використаної літ ер атури}

1. Віленський А. Б. Концепція державного регулювання медичного забезпечення дітей в Україні // Державне управління: удосконалення та розвиток: електронне наукове фахове видання. - 2012. - № 10 [Електронний ресурс] - Режим доступу: http:// www.dy.nayka.com.ua/?op $=1 \& z=518$ 
2. Устінов O. В. Забезпечення права дитини на охорону здоров'я: стратегічні заходи державної політики // Укр. мед. часопис. - 2013 [Електронний ресурс]. - Режим доступу: http://www.umj.com.ua/wp/wpcontent/uploads/2013/09/Pediatrics. pdf?upload=

3. Слабкий Г. А., Пархоменко Г. Я. К вопросу о реформировании системы здравоохранения: международный опыт // Укр. мед. часопис. - 2012. - № 3. - С. 26-29.

4. WHO Global Health Observatory Data Repository - Geneva, World Health Organization, 2013. [Electronic resource]. - Access to the resource: http://apps.who. int/ gho/data/view.main

5. Квіташвілі O. Національна стратегія реформування системи охорони здоров’я в Україні на період 2015-2020 років [Електронний ресурс]. - Режим доступу: http:// healthsag.org.ua/wpcontent/uploads/2014/11/ Strategiya_UKR.pdf

6. Гойда Н. Г., Корицький Г. I. Концепція реформування педіатричної служби в Тернопільській області // Укр. мед. часопис. - 2013. - № 4. - С. 135-138 [Електронний ресурс]. - Режим доступу: http://nbuv.gov.ua/UJRN/UMCh_2013_4_28

7. Панфілова Г. Л. Фармацевтична допомога як історична, нормативно-правова та соціально-економічна категорія в системі охорони здоров'я і фармацевтичному забезпеченні населення (2014) [Електронний ресурс]. - Режим доступу: http://dspace. zsmu.edu.ua/bitstream/123456789/693/1/AP_1402_089-097.pdf

8. Корицький Г. I. Дитяча смертність як інтегральний показник медико-соціальної допомоги дітям // Здобутки клін. експеримент. медицини. - 2012. - № 2 (17). - С. $62-65$.

9. Европейская база данных «Здоровье для всех» - Копенгаген, Европейское региональное бюро ВОЗ, 2012 [Электронный ресурс]. - Режим доступа: http://data.euro. who.int/hfadb/shell_ru.html

10. Павлов В. В., Суслин С. А., Галкин Р. А., Шешунова С. В. Моделирование конечных результатов в системе управления качеством медицинской помощи // Менеджер здравоохранения. - 2013. - № 10. - С. 18-22.

11. Майданник В. Г. Сучасні проблеми та перспективи розвитку педіатрії в Україні // Здоров’я України. - 2015 [Електронний ресурс]. - Режим доступу: http://healthua.com/articles/1406.html

12. Serious childhood problems in countries with limited resources [Electronic resource]. - Access to the resource: http://www.who.int/child-adolescent-health $/ \mathrm{New}_{-}$ Publications/CHILD_HEALTH/ISBN_92_4_156269_2.pdf

13. Якимець В. М., Іващченко С. М., Лобода T. В. Перспективи застосування муніципальних систем охорони здоров'я в умовах України // Вісн. соціальної гігієни та організації охорони здоров’я України. - 2012. - № 1. - С. 82-85.

14. Гойда Н. Г., Донець В. С. Актуальність створення перинатальних центрів в Україні // Здоровье женщины. - 2012. - № 4. - С. 14-16.

15. Вафин А. Ю., Сунгатов Р. Ш., Туишев Р. И. В основе стратегии управления отраслью - концентрация ресурсов и их более эффективное использование // Healthy Nation дайджест. - 2012. - № 10. - С. 34-39.

16. Сірик В. О. Оцінка і необхідність реформування первинної медичної допомоги в Україні // Галицький лікарський вісн. - 2012. - Т. 19, № 4. - С. 134-136.

17. Корнійчук $O$. П. Стан первинної медико-санітарної допомоги на засадах сімейної медицини в Україні // Укр. мед. часопис. - 2012. - № 2. - С. 146-150.

18. Европейское региональное бюро ВО3 (2010а). Европейская база данных «Здоровье для всех» (HFA-DB) - Копенгаген, Европейское региональное бюро ВО3, 2011 [Электронный ресурс]. - Режим доступа: http://www.euro.who.int/hfadb

19. Антипкін Ю. Г., Резниченко Ю. Г., Яриеева М. О. Вплив факторів навколишнього середовища на стан здоров'я дітей раннього віку // Перинатология и педиатрия. - 2012. - № 1 (49). - С. 48-51. 
20. Конвенція ООН про права дитини, прийнята резолюцією 44/25 Генеральної Асамблеї ООН від 20 листопада 1989 року. - 1991 [Електронний ресурс]. - Режим доступу: http://www.unicef.org/ukraine/ukr/children_11699.html Редакція від 20. 11. 2014, підстава 995_160

21. Конституція України. Закон Украины від 28. 06. 1996 р. № 254к/96-ВР [Електронний ресурс]. - Режим доступу: http://zakon2.rada.gov.ua/laws/ show/254к/96-вр

22. Про схвалення Концепції реформи фінансування системи охорони здоров'я. Розпорядження КМУ від 30. 11. 2016 р. № 1013 [Електронний ресурс]. - Режим доступу: http://www.apteka.ua/article /396802

23. Жилка К. І., Кризина Н. П. Законодавче та нормативно-правове забезпечення охорони здоров'я дітей в Україні на сучасному етапі реформування галузі // Державне управління: удосконалення та розвиток: електронне наукове фахове видання. - 2012. - № 5 [Електронний ресурс]. - Режим доступу: http://www.dy.nayka.com. ua/ $\mathrm{op}=1 \& \mathrm{z}=413$

24. Основи законодавства України про охорону здоров’я. Закон України № 2802XII від 19. 11. 92 (із змінами) [Електронний ресурс]. - Режим доступу: http://zakon1. rada.gov.ua/laws/

25. Корнійчук О. П. Удосконалення економічного механізму розвитку первинної медико-санітарної допомоги в Україні // Укр. мед. часопис. - 2012. - № 3. - С. 127 133.

26. Корнійчук О. П. Соціальні складові структури індикаторів якості надання медичної допомоги // Ліки України. - 2013. - № 2 (15). - С. 50-56.

27. Радиш Я. Ф., Поживілова О. В., Васюк Н. О. Кадрове забезпечення охорони здоров’я України: сутність понять // Економіка та держава. - 2012. - № 1. - С. 97-101.

28. Матеріали сайту http://mtd.dec.gov.ua/index.php/uk/reiestr-mtd

29. Державна політика у сфері охорони дитинства. Ретроспектива та проблеми сьогодення [Електронний ресурс]. - Режим доступу: http://www.ugcc. lviv.ua/actual/ articles/

30. Слабкий Г. А., Пархоменко Г. Я. К вопросу о реформировании системы здравоохранения: международный опыт // Укр. мед. часопис. - 2012. - № 3. - С. 26-29.

31. De Sanctis V., Filati G., Fiscina B. et al. Adolescent health care in Italy: a minireview // Georgian Medical News. - 2012. - N 210. - P. 8-12.

32. Basu S., Andrews J., Kishore S. et al. Comparative performance of private and public healthcare systems in low - and middle-income countries: a systematic review // PLoS Med. - 2012. - V. 9, N 6. - P. e1001244. doi: 10.1371/journal.pmed.1001244. Epub 2012 Jun 19.

33. Рингач Н. О. Оцінка досягнення цілі розвитку тисячоліття щодо зниження дитячої смертності в Україні // Демографія та соціальна економіка. - 2013. - № 2 (20). - C. 28-39.

34. Towards a grand convergence for child survival and health: a strategic review of options for the future building on lessons learnt from IMNCI [Electronic resource]. - Access to the resource: http://www.who.int/maternal_child_adolescent/documents / strategic-review-child-health-imnci/en/

35. Вороненко Ю. В., Гойда Н. Г., Мойсеєнко Р. О. Сучасні аспекти розвитку системи медико-соціальних послуг для уразливих груп дітей в Україні // Укр. мед. часопис. - 2015. - № 1 (105) [Електронний ресурс]. - Режим доступу: http://www.umj.com. ua /article/83917

36. Про впровадження стратегії інтегрованого ведення хвороб дитячого віку. Наказ МО3 України № 581 від 15. 07. 2010 [Електронний ресурс]. - Режим доступу: http://www.uapravo.net/akty/postanova-osnovni/akt8tdde9f.htm 
37. Вороненко Ю. В., Шекера О. Г., Ткаченко В. І. та ін. Підходи до підготовки сімейних лікарів в Україні та країнах Свропи // Укр. мед. часопис. - 2014. - № 3 (101) [Електронний ресурс]. - Режим доступу: http://www.umj. com.ua/article/75706/ pidxodi-dopidgotovki-simejnix-likariv-v-ukraini

38. Lekhan V. N., Rudiy V. M., Shevchenko M. V. et al. Ukraine: Health system review // Health Systems in Transition. - 2015. - V. 17, N 2. - P. 1-153.

39. Tenore A. 4th Global Pediatric Summit: Exploring Standards for Training, Assessment, and Physician Accreditation. 25-26 April 2012, P. 42.

40. Крючко Т. О., Кушнерева Т. В., Вовк Ю. О. Роль педіатра в умовах реформування галузі охорони здоров’я // Семейная медицина. - 2015. - № 6 (62). - С. 147-149.

41. Кірова М. О. Окремі питання фінансування системи охорони здоров'я в Україні в умовах реформування галузі // Держава та регіони. - 2012. - № 2. - С. 212-214.

42. Фінальна редакція Національної стратегії реформування системи охорони здоров'я в Україні на період 2015-2020 років [Електронний ресурс]. - Режим доступу: http://www.apteka.ua/article/327094

43. Держбюджет-2016: загальні показники та видатки на охорону здоров'я [Електронний ресурс]. - Режим доступу: http://www.apteka.ua/article/356530

Надійшла до редакції 13 лютого 2017 року.

В. В. Трохимчук ${ }^{1}$, О. И. Беляева ${ }^{2}$, Л. М. Унгурян ${ }^{2}$

${ }^{I}$ Национальная медичинская академия последипломного образования имени П. Л. Шупика, г. Киев

${ }^{2}$ Одесский национальный медииинский университет

ОРГАНИЗАЦИЯ ПРЕДОСТАВЛЕНИЯ МЕДИЦИНСКОЙ ПОМОЩИ ДЕТЯМ В УКРАИНЕ (ОБЗОР ЛИТЕРАТУРЫ)

Ключевые слова: дети, лекарственные средства, здравоохранение, медицинская помощь

А Н Н О Т А ЦИ Я

Реализация медицинских мероприятий высокого качества, направленных на охрану здоровья детей, остается важным вопросом на этапе реформирования отечественной медицины. Цель работы - изучить и проанализировать систему медицинской помощи детям в Украине. Объектом исследования были нормативноправовые акты, регулирующие организацию медицинской помощи детям. Методы исследования: информационный, ретроспективный, исторический, логический, аналитический.

Анализ нормативно-правовых документов, регулирующих организацию оказания медицинской помощи детям, установил их формальность и экономическую необоснованность.

По состоянию на январь 2017 г. в Реестр медико-технологических документов по направлению «Педиатрия» вошло только 35 документов. Т. е. многие патологические состояния детского возраста не охвачены стандартизацией, что снижает качество оказания медицинской помощи.

Государственные программы по улучшению состояния здоровья детей остались нереализованными в связи с недостаточным финансированием, несогласованной координацией между исполнителями программы, отсутствием действенного мониторинга качества и результатов выполнения государственных программ. Результатом внедрения стратегии «Интегрированное ведение больных детского возраста» стало снижение показателей смертности детей различных возрастных групп 
в пилотных регионах. В условиях реформирования отрасли наиболее эффективной и приемлемой моделью оказания педиатрической помощи является комбинированная (III модель).

Расходы населения достигают почти половины общего объема финансирования отрасли, что свидетельствует о несоответствии между реальным состоянием обеспечения детского населения в системе здравоохранения Украины и государственными нормативными документами.

Определена необходимость структурной реорганизации отрасли, оптимизации коечного фонда, увеличения объемов финансирования медицинской помощи из государственного и местных бюджетов и повышения эффективности использования ресурсов отрасли здравоохранения, продолжения разработки и внедрения современных протоколов (стандартов) лечения патологий детского возраста.

V. V. Trokhimchuk ${ }^{1}$, O. I. Belyaeva ${ }^{2}$, L. M. Unhurian ${ }^{2}$

${ }^{1}$ Shupyk National Medical Academy of Post-graduate Education, Kyiv

${ }^{2}$ Odesa National Medical University ORGANIZATION OF MEDICAL CARE FOR CHILDREN IN UKRAINE (REVIEW OF LITERATURE)

Key words: medications, children, healthcare, medical care

A B S T R A C T

The realization of high quality medical measures for protecting children's health remains an important issue at the stage of reforming the domestic medicine. The aim of this work was to study and analyze the system of medical aid for children in Ukraine. The research focused on normative-legal acts regulating the organization of medical aid for children. The research methods are informative, retrospective, historical, logical and analytical.

The analysis of normative-legal documents regulating the organization of rendering of medical aid for children established their formality and economic groundlessness.

According to January 2017, only 35 documents were included into the Registry of medical technological documents in the direction of «Pediatrics». It means that many children's pathological states are not covered by standardization, what reduces the quality of medical aid.

The national programs for the improvement of health status of children remained unrealized due to the lack of funding, ill-coordinated links between program implementers, the lack of effective monitoring of the quality and results of realizing the state programs. The implementation result of IMChI strategy was the reduction of mortality rate in children of different age groups in the pilot regions. In terms of reforming the combined model (model III) is the most effective and acceptable for pediatric care rendering.

The population expenses reach nearly half of the total funding of the sector, what demonstrates the inconsistencies between the real state of children's assurance in the health care system of Ukraine and national normative acts.

It was determined the necessity of structural reorganization of the system, the optimization of beds number, the increase of medical care funding from state and local budgets, the raising of resource efficiency of health care system and the continued development and implementation of modern protocols (standards) for the treatment of children pathologies.

Електронна адреса для листування завторами: tvvо@ukr.net 